\title{
水素イオン照射による黒鉛 の照射促進昇華プロセス
}

日野友明*, 高杉裕司*, 山科俊郎*

(平成 3 年 6 月 13 日受理)

\section{Process of Radiation-Enhanced Sublimation of Graphite due to Hydrogen Ions}

\author{
Tomoaki Hino*, Yuji Takasugi* and Toshiro Yamasina* \\ *Department of Nuclear Engineering, Hokkaido University, \\ Kita-13, Nishi-8, Kita-ku, Sapporo 060, Japan
}

For radiation-enhanced sublimation (RES) of graphite, a simple model is proposed. The model shows that the produced interstitials which escape the recombination with vacancies can reach the surface and evaporate. Only a small fraction of interstitials contribute to the RES yield. The dependences on energy, mass and incident angle of ion are explained based on this mode. The changes of surface morphology and structure due to the RES are investigated. It is found that the interstitials and vacancies are completely mixed in the surface and thus the structure change becomes the same for every graphite material. From this result, it is suggested that the RES yield becomes the same even if the graphite texture is different. In order to suppress the RES, thus it is important to reduce the heat flux to the graphite wall in a fusion reactor.

KEYWORDS: Radiation Enhanced Sublimation, Graphite, Simple Model, RES yield, Surface Structure

\section{1.はじめに}

黒鉛材料は低原子番号物質であり熱伝導性むよいこと から, 今まで, 核融合装置のリミター, アーマータイル,

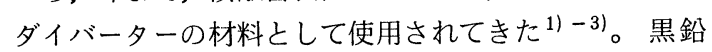
に水素イオンが入射すると, 室温では物理スパッタリン グ, 500 600 ${ }^{\circ} \mathrm{C}$ では化学スパッタリング4)によりエロ ージョン (損耗) してしまう。化学スパッタリングでは 炭素は主としてメタン $\left(\mathrm{CH}_{4}\right)$ の形で放出され, その収 率は約 0.1 で物理スパッタリングより 1 桁大きい。との

* 北海道大学工学部原子工学科： $\mathbf{T} 060$ 札幌市北区 北13 西 8
ため化学スパッタリングの収率, 放出される炭化水素の 種類と量, メカニズムなどについて多くの研究が行われ てきた。現在, 国際協力で設計が進められている核融合 実験炉, ITERでは黒鉛がダイバーターおよび第一壁 の候補材料となっている5),6)。乙の装置では, ダイバー タ一板の温度は $1000^{\circ} \mathrm{C}$ 以上, 場合によっては $2000^{\circ} \mathrm{C}$ 以 上になると予測されている。乙の温度領域では, スパッ タリング収率が約 1 程度の照射促進昇華（RadiationEnhanced Sublimation) が起り, 黒鉛は著しくエロ ージョンしてしまう。てれは ITERのダイバーター設 計において大きな問題となっている。

$\mathrm{RES}$ は約 $1000^{\circ} \mathrm{C}$ 以上で起り, 温度ととむに指数関 数的に上昇する ${ }^{7), 81}$ 。放出される粒子は, 主として単体 
の炭素原子や分子であるととがわかっている8!。放出さ れる粒子は, $\mathrm{C}$ が圧倒的に多く, 次いで $\mathrm{C}_{2}, \mathrm{C}_{3}$ の順に なっている。放出された炭素原子や分子のエネルギー分 布は物理スパッタリングのものとは異なり,むしろ熱昇 華に近く ${ }^{9)}$, 近似的にターゲット温度に対応したマック スウエル分布で表わされる。乙の他, RES の特徵とし て次の点があげられる。 RES は入射イオンの種類に依 存せずおてるが, エロージョン収率は入射イオン質量と ともに増加する7)。 RES のみかけの活性化エネルギー は, $0.54 \sim 1.1 \mathrm{eV}$ であるが ${ }^{10)}$, 乙の值は, 通常の熱昇華 のあの ( $7.4 \mathrm{eV})$ に比べ約 1 桁屯低い。入射イオンの角 度をかえて収率の角度依存性を求めたとてろ, 入射角度 とと屯に若干増加する傾向にあったが゙11), 物理スパッタ リングのような強い角度依存性はみられていない。入射 イオン束をかえて収率のフラックス依存性が調べられて いるが ${ }^{12)}$, 収率化対するフラックス依存性はみられて いない。

RESのモデルについてあ Roth ら ${ }^{13)}$ が考察しており, RES Kは3つのステップがあるとしている。即ち, (1) 照射による格子間原子の生成, (2) 格子間原子の表面まで の拡散, (3) 格子間原子の表面からの蒸発である。乙れら のプロセスをもとに解析モデルを考え，また，いくつか のパラメーターの值を仮定して R E S 収率の温度依存性 および入射イオンの質量依存性について検討している13!。 RES の概要は比較的わかってきたが，まだ十分には解 明されていない点がいくつか残っている。例えば, 活性 化エネルギーはどのプロセスで決るのか, 特性がかなり 違っている黒鉛の収率はどうなるのか, RESを受けた 表面構造はどのように変るのか等である。本報告では, 当研究室で行われてきた一連の RES 亿関する実験結果 14)をむとに, てれらの点について検討する。

\section{2. 照射促進昇華プロセスについて}

R ES 収率を説明するため, Roth らはイオン衝擊に よりつくられるフレンケルペアー, 即ち格子間原子と空 孔に対して拡散方程式をたてて, TRIM コードで数值 計算した ${ }^{13)}$ 。乙てでは, 直観的に RES を理解するため 簡単なモデルを考える。まず, Fig. 1 亿示してあるよう に入射イオンのレンジ近傍, $x$ で $\Delta x$ の領域にフレンケ ルペアーがつくられたとする。空孔に比べて, 格子間原 子の拡散がはやいと仮定して, 格子間原子が表面に到達 するフラックスを求めよう。イオンにより生成される格 子間原子は空孔と再結合しながら拡散する。また, 原理 的に格子間原子の密度勾配がなくても拡散は扔てる。乙 の場合,アインシュタインの関係式 ${ }^{15)}$ が適用できる。す なわち, 表面に到達する時間をてとすると, 格子間原子

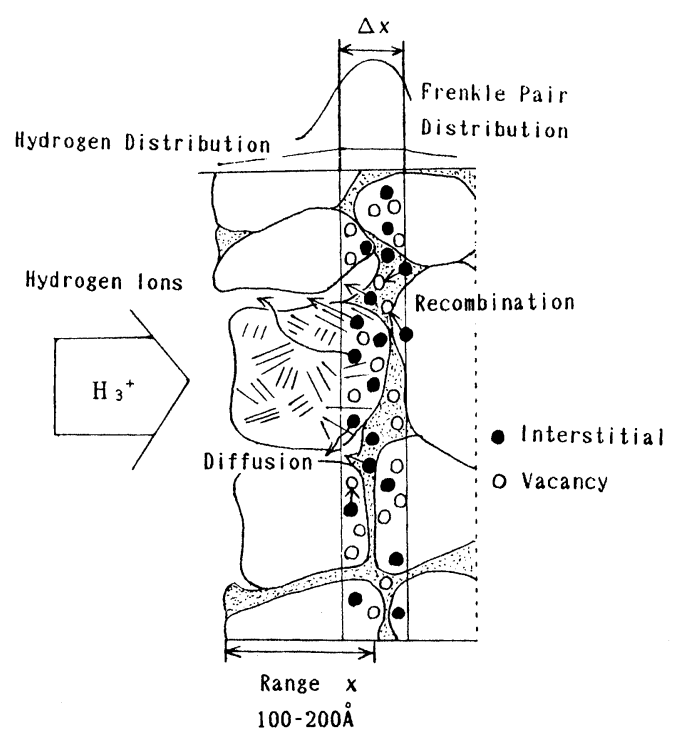

Fig. 1 Process of radiation enhanced sublimation.

の拡散係数 $D=D_{0} \exp \left(-E_{a} / k T\right)$ 之距離 $x$ との関係 は, $x^{2}=2 D \tau$ で与えられる。乙てで, $E_{a}$ は R ES の みかけの活性化エネルギーである。一方, 空孔が存在す る領域を通過する際, 空孔と再結合するが, それを逃れ 表面侄到達する確率は, $\exp \left(-\alpha n_{V}(\Delta x)^{2} / 2 D\right)$ となる。 ここで, $\alpha$ 抢よび $n_{V}$ は各々再結合率および空孔密度で ある。

一方, 黒鉛中には数 $\mu \mathrm{m}$ のポアが存在するが, 数 $\mathrm{keV}$ 水素イオンの平均レンジ (飛程) は高々数 $100 \AA$ なので, 拡散に対するポアの影響は無視できる。したがって, 格 子間原子の表面に到達するフラックスは次式で与えられ る。

$$
\begin{aligned}
J & \simeq\left(\Delta x n_{i} / \tau\right) \exp \left(-\alpha n_{V}(\Delta x)^{2} / 2 D\right) \\
& =\left(2 \Delta x n_{i} / x^{2}\right) D \exp \left(-\alpha n_{V}(\Delta x)^{2} / 2 D\right)
\end{aligned}
$$

ここで, $n_{i}$ は距離 $x$ に打ける格子間原子密度である。 入射イオン束を $\phi_{i}$ とすると RES 収率は, $y=J / \phi_{i}$ と なる。乙の(1)式をもとにして, RESのいくつかの特徵 について考察する。

高速イオンが物質中に入射したとき，その速度が物質 を構成している原子の外殸電子の軌道速度より小さいと き, 電子の電離や励起等の非弾性衝突は起りにくく, む しろ原子核との弾性衝突が主として起てる ${ }^{16)}$ 。電子の軌 道速度をボーア速度とすると, 乙の状況は水素イオンエ ネルギーが $25 \mathrm{keV}$ 以下の時に相当する。乙の過程は 2 体間のクーロンポテンシャルによるラザフォード散乱で 
記述される。したがって, 入射イオンは主として弾性衝 突で減速していくと仮定される。入射イオンの質量を $m_{1}$, 炭素原子の質量を $m_{2}$, 入射イオンエネルギーを $E$ とすると, 炭素原子が衝突の際受けとる最大エネルギ 一は $T_{\max }=4 m_{1} m_{2} /\left(m_{1}+m_{2}\right)^{2} \cdot E$ となる。炭素原 子が 1 回の衝突で平均 $T_{\max } / 2$ のエネルギーを受けとる と近似すると, 水素イオン $\mathrm{H}^{+}$が入射する場合, 約 7 回 の衝突で全エネルギーを失う。 R ES が起こるには, ま ずフレンケルペアーが生成されなければならない。すな わち, $T_{\max }$ がはじき出しエネルギー $E_{d}$ より大きくなけ ればならない。したがって, E> $3.5 E_{d}$ がRESのため の必要条件となる。一方，入射エネルギーが大きすぎる と,レンジが長くなり表面まで到達できるフラックスは 減少する。乙れらの点から RES にはしきいエネルギー が存在するが, エネルギーが大きすぎると表面へのフラ ックスが減るととになる。乙の傾向は, Haasz ら ${ }^{12)}$ の 実験結果によく対応している。

入射イオンの質量が大きいとレンジ $x$ が短くなるとと 屯に, 衝突の際炭素の受けとるエネルギーも大きくなる。 しかし，エネルギーを失うまでの衝突回数は減る。実験 データでは入射イオンの質量とともに R E S 収率が上昇 している11)。乙れは前者の方が支配的であるととを示し ている。また, イオンの入射角度がターゲット表面に対 して平行に近くなるほどレンジ $x$ は短くなる。したがっ て, フレンケルペアーの位置も浅くなるので, 収率は増 加しよう。 RESでは, 表面までの拡散プロセスで再結 合による格子間原子の消滅が存在するため, 入射角度依 存性は物理スパッタリングのようには顕著にならない之 考えられる。実験データ11)で角度依存性が強くみられ ないのは,このためとみなせる。

水素イオンによる RES 収率は, 黒鉛温度が約 2000 ${ }^{\circ} \mathrm{C}$ でほぼ 1 となる。1ケの水素イオンがつくりだすフ レンケルペアー数は平均約 7 である。乙の点から,つく りだされるほとんどの格子間原子は拡散過程で空孔と再 結合して消滅しているてとがわかる。もし, 空孔の密度 が増えるなら再結合による消滅屯顕著になろう。入射イ オン束を増やせば空孔の密度も増加するはずである。 Haasz ら ${ }^{12)}$ は入射水素イオン束を $\phi=10^{13-16} \mathrm{H} / \mathrm{cm}^{2} ・ \mathrm{~s}$ の範囲にして R ES 収率のフラックス依存性を調べたが, まだ顕著な依存性を確認していない。

\section{3. 照射促進昇華による表面形態および 構造の変化}

北大 ECR 水素イオン源 ${ }^{14)}$ で種々の黒鉛材料に対し て水素イオンを照射し, RES 収率の温度依存性, 表面 形態の変化および構造の変化について調べた。イオン種
は $\mathrm{H}_{3}{ }^{+}$, エネルギーは $4.5 \mathrm{keV}$, イオン束は $10^{15} \mathrm{H} / \mathrm{cm}^{2} ・ \mathrm{~s}$ である。入射イオンは $\mathrm{H}_{3}{ }^{+}$であるが, 表面ですぐに解 離して $\mathrm{H}$ 原子と $\mathrm{H}^{+}$イオンになると考えられる。解離工 ネルギーは数 $\mathrm{eV}$ なで, 入射エネルギーに較べてかな り小さい。解離した水素原子あるいはイオンの平均エネ ルギーは約 $1.5 \mathrm{keV}$ みなせる。ほかの詳しい実験条件 は先回の報告14) にまとめられている。

Fig. 2 亿等方性黒鉛, ISO-880U 試料の照射前および 照射後の SEM 写真による表面形態が示されている。 物理スパッタリングされると角ばった部分は丸みを帯び てくるが, 化学スパッタリングを受けるとさらに小さな 凸凹が発達する。物理スパッタリングされても，黒鉛表 面形態の原形はほぼ保たれている。化学スパッタリング についても, ほぼ同様であるといえよう。とてろが, RESを受けた表面は,未照射のものと全く異なりスポ ンジ状に変化した。未照射の表面構造の原形はほとんど みられなくなっている。照射量は約 $10^{19} \mathrm{H} / \mathrm{cm}^{2}$ であり, この条件下ではレンジ内（約 100～200 ̊) の炭素原子は 幾度も格子点からはじきだされることになる。物理スパ ッタリングが起こる室温下では, 格子間原子はほとんど 移動せず，表面近傍のみの炭素が放出するであろう。し たがって, 形態は全体的に変らず，角ばった部分のみが 丸くなったとみなせる。一方，RESが起こる高温下で は,できた格子間原子はすみやかに拡散して空孔と再結 合したり，一部は表面から蒸発する。空孔同士も結合す るであろう。このプロセスが繰り返され，格子間原子も 空孔屯完全にミキシングされてしまう。乙れらの理由か ら，RESをある程度受けると表面は全く原形を失い， スポンジ状になると考えられる。化学スパッタリングが 起乙る温度下では, 物理スパッタリングおよび R ES の 中間の形態へ変化するとみなせる。

ラマンスペクトルをみると, RES を受けても結晶構 造がかなり回復していくことがわかった ${ }^{14)}$ 。れは，高 温下で格子間原子と空孔との再結合が促進されたためと 考えられる。一方, 物理スパッタリングされた後は構造 はアモルファス的になった。化学スパッタリングの後で は，構造は両者の中間的なものとなった。照射温度が低 いと水素保持量む多いこと, および再結合も起とりにく いことからアモルファス的構造になりやすい。 RESを 受けた表面に対するラマン分析結果は, 表面形態の变化 にほぼ対応しているてとがわかった。

$\mathrm{C} / \mathrm{C}$ コン゚ジットのマトリックス部の形態変化は等 方性黒鉛と同じであったが, ファイバー部表面は RES を受けるとしわ状に変化した。乙の理由ははっきりしな いが,ファイバー部は配向性がよいので，屯し配向性の よい部分に格子間原子がエピタキシャル成長するならし 


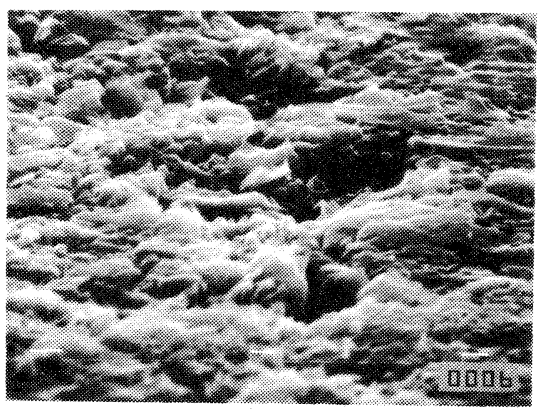

Physical Sputtering $\mathrm{RT}$

$3.4 \times 10^{19} \mathrm{H} / \mathrm{cm}^{2}$

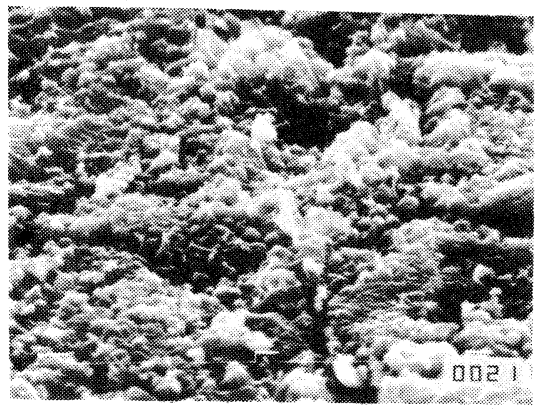

Chemical Sputtering $900 \mathrm{~K}$

$1.1 \times 10^{19} \mathrm{H} / \mathrm{cm}^{2}$

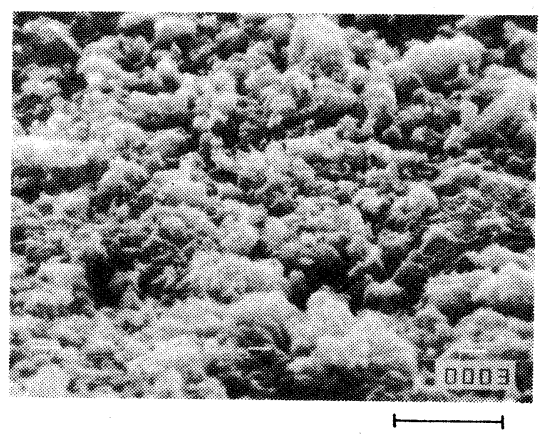

$5 \mu \mathrm{m}$

RES

$$
\begin{gathered}
2000 \mathrm{~K} \\
1.0 \times 10^{19} \mathrm{H} / \mathrm{cm}^{2}
\end{gathered}
$$

Fig. 2 SEM photographs of ISO-880U after irradiation at different temperatures.
わ状の構造が生じる可能性がある。

構造が異なる種々の黒鉛材料, 等方性黒鉛, C/C コン ポジット, 熱分解炭素について, 照射前後の構造をラマ ン分光法で調べたとてろ，照射前はどれも異なった構造 であったが，RESが起てる温度で照射すると，どの黒 鉛も同じ構造となった ${ }^{14)}$ 。乙の結果は, 表面形態の変化 と同様,レンジ内で格子間原子抢よび空孔がミキシング してしまうことによる。すなわち, 表面が照射前の構造 を完全に失い, 結晶構造の回復はアニーリング効果によ るので照射温度およびフルエンスが同じなら表面構造は どれも同じになる。照射温度を上げていくと, 結晶性黒 鉛構造の方が欠陷性黒鉛構造より相対的に発達していく ことがわかっている14!。

Fig. 3 に種々の黒鉛に対する R ES 収率の温度依存

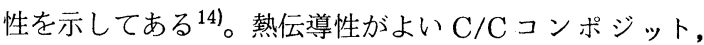
熱分解炭素と屯等方性黒鉛と同じ温度依存性を示した。 この結果は表面形態の変化および構造の変化から考えれ ば当然であるといえよう。すなわち，どのような黒鉛材 料を用いても R ES を抑えるてとができない。また, み かけの活性化エネルギーの平均值は約 $0.7 \mathrm{eV}$ となった。 この值は,今まで得られた結果 $($ 約 $1 \mathrm{eV})$ とほぼ同じで ある。ただし, 温度が高い領域では活性化エネルギーは 若干大きくなる傾向を示した。格子間原子のベイサル面 に沿った拡散の活性化エネルギーは約 $0.1 \mathrm{eV}$, 垂直方向 では数 $\mathrm{eV}$ であるから, RES が起こる領域の活性化エ ネルギーはこれらの中間の值となろう。すなわち,

$$
D \sim C \perp D_{\perp} \mathrm{e}^{-E_{\perp} / k T}+C_{/ /} D_{/ /} \mathrm{e}^{-E_{\| / /} / k T}
$$

で表される。乙こで, C は定数であり，(2)式の第 1 項お

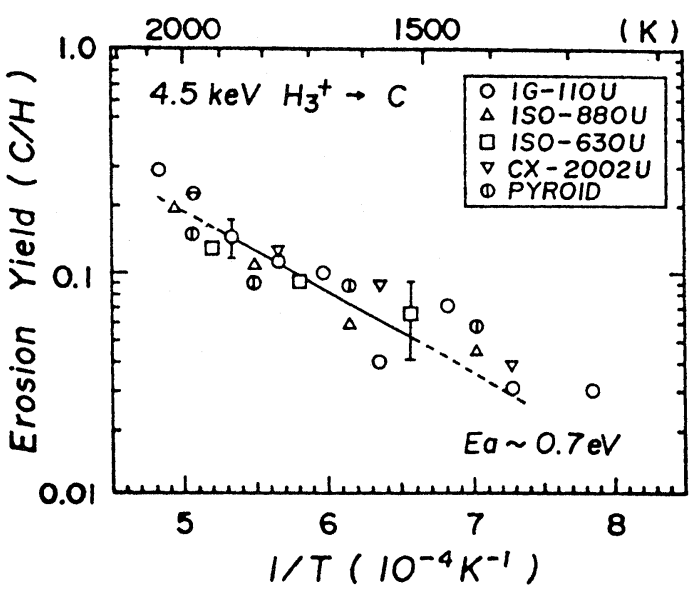

Fig. 3 Temperature dependence of RES for several graphite materials. 
よび第 2 項は, 各々炭素結晶の $a b$ 面に対して垂直方向 拉よび平行方向の拡散の寄与である。温度が高くなると 結晶構造がかなり回復するので, 拡散しにくくなり第 1 項に起因する拡散プロセスが顕著となるであろう。この 場合, 活性化エネルギーが大きくなり得る。表面に到達 した格子間原子の蒸発の活性化エネルギーは $0.1 \mathrm{eV}$ 以下 であるから， RESのみかけの活性化エネルギーは拡散 プロセスで決るとみなせる。

\section{4. まと め}

$\operatorname{RES}$ プロセスに対して, 簡単なモデルを考え, 入射 イオンのエネルギー, 質量, 角度等を考察した。特に, 入射イオンのレンジ, 格子間原子の空孔との再結合によ る消滅プロセスが重要であるととを指摘した。RES下 での照射実験から, RESを受けるとレンジ内の表面領 域は完全に破壊されるとと,すなわち格子間原子と空孔 のミキシングが起ることがわかった。そして生成された 格子間原子の多くは再結合で消滅し, 再結合を逃れた格 子間原子のみが蒸発する。乙のため, 表面形態はスポン ジ状あるいはしわ状になるとと, 結晶構造はアニーリン グ効果のみにより回復されることを統一的に説明できた。 ごのような黒鉛です R ES は起り，その収率はほぼ同じ になることを指摘した。

格子間原子の拡散プロセスを調べると, 活性化エネル ギーは主として拡散によりきめられることがわかった。 ただし, この拡散過程はかなり空孔との再結合による消 滅が含まれているあのである。活性化エネルギーはみか け上, ベイサル面に垂直なあのと平行なあのとの中間に なるとと, 照射温度により結晶構造が異なってくるので 活性化エネルギーむ温度により変り得ることを指摘した。 本研究の結果から, どのような黒鉛を用いても照射促 進昇華を抑えるととができないことがわかったので, 核 融合炉の内壁に黒鉛を適用する場合, 熱負荷をさげて RESが起こらない温度にしたり, 黒鉛に金属を混合さ せたりする必要があろう。金属をカーバイドの形で黒鉛 に混入させた場合, 照射促進昇華の始まる温度を若干高 くできようが, 約 $1000^{\circ} \mathrm{C}$ 以上で金属が蒸発してしまう。 金属混合黒鉛が多くの放電にさらされると金属が抜けて 黒鉛になってしまう。したがって, 黒鉛材料を核融合炉
のダイバーター等の内壁に使用する際, 熱負荷の低減が 不可欠となる。

\section{謝辞}

本研究のため各種黒鉛材料を提供して下さった東洋炭 素(株)感謝いたします。

\section{文献}

1) 山科俊郎, 昭和 61 年度一平成元年度文部省科学研究 費補助金〔核融合特別研究〕研究成果報告書〔核融 合炉第一壁としての黒鉛共通材料の総合的特性評 価了, 北海道大学工学部 (1990 年, 2月)

2) 日野友明, 山科俊郎, 炭素1988 [No.130] 118

3) 高津英幸, 奥 達雄, 炭素1988 [No.135] 286

4) 例えば, R. Yamada et al. J. Nucl. Mater. 95 (1980) 276

5) 溝口忠憲, 下村安夫, 核融合研究 65 (1991) 115

6) 関 昌弘, 秋場真人, 私信 (1991)

7) J. Roth et al. J. Nucl. Mater. 111 \& 112 (1982) 775

8) V. Philipps et al. J. Nucl. Mater. 111 \& 112 (1982) 781

9) E. Vietzke et al. Nucl. Instr. Meth. B2 (1984) 617

10) J. Roth et al. J. Nucl. Mater. 122 \& 123 (1984) 1447

11) J. Roth et al. J. Nucl. Mater. 165 (1989) 193

12) A. A. Haasz et al. J. Nucl. Mater. 151 (1987) 77

13) J. Roth et al. Nucl. Instr. Meth. B7/8 (1985) 788

14) 高杉裕司, 福田 伸, 広烟優子, 日野友明, 山科俊 郎, 炭素 1991 [No. 147] 80

15) Edited by H. L. Anderson, Physics Vade Mecum, p. 312, American Institute of Physics (1981)

16) 中村勝吾, 表面の物理, p. 51, 東京大学出版会 (1982) 